\title{
A study on Physicochemical and Microbiological Evaluation of Tap Water of Bidar District, India
}

\author{
Dhote Lina $^{1 *}$, Arun Kharate ${ }^{1}$, Basavaraj Awati ${ }^{2}$ and Saste Ashwini ${ }^{3}$ \\ ${ }^{1}$ Department of Veterinary Public Health and Epidemiology, ${ }^{2}$ Department of Veterinary \\ Microbiology, ${ }^{3}$ Department of Institutional Livestock Farm Complex, \\ Veterinary College Bidar, Karnataka India \\ *Corresponding author
}

\section{Keywords \\ Physico-chemical, Microbiological analysis, Hardness, Nephelometric Turbidity Unit, Most probable number}

Article Info

Accepted: 04 March 2019 Available Online: 10 April 2019

\section{A B S T R A C T}

The present study was undertaken to evaluate the physicochemical and microbiological analysis of water of the Bidar district, Karnataka. Tap water samples $(n=82)$ were collected from 05 talukas of Bidar district. The samples were subjected to physical analysis. The parameters included were hardness, $\mathrm{pH}$, total dissolved solids, turbidity, color, and taste. Chemical parameters included were nitrates, nitrites, chloride, ammonia, fluoride, lead, arsenic, iron, sulfates and copper. The bacteriological examination of water sample includes the most probable number of presumptive coliform as suggested by WHO (1971) \& BIS (1991). The physical tests were performed by subjecting the water samples using physical parameter testing equipment and chemicals. Chemical parameters were tested by using prescribed chemicals and following standard protocols. The bacteriological quality of the water was tested by following standard protocol of most probable number procedure. The $\mathrm{pH}$ of the 72 samples shown range from 6.5 to 8.5 which is the acceptable limit by WHO but the remaining 10 samples, from that 9 sample shown $\mathrm{pH}$ range 8.9-9.3 and one sample has shown PH 6.1. The turbidity of the water sample ranged from 0.5 to 2.85 Nephelometric Turbidity Unit (NTU) which is well below the maximum permissible limits i.e. 5 NTU (WHO). The total hardness of the 65 samples shown ranges from 65-145 ppm which is the acceptable range (moderately hard water) for drinking water whereas 17 samples shown ranges from 150-250 ppm indicating hard water. The chemical evaluation of the sample shown negative to all the parameters mentioned above except chloride which was positive in 07 samples. In the bacteriological analysis, the most probable number (MPN) count ranged from 03 to 1100 for 13 samples and rest 69 samples shown a negative result for coliforms. From 08 MPN positive samples, E.coli was isolated by the standard microbiological procedure. To conclude water samples under the area of investigation shown a range of quality ranging from unfit for consumption to fit for consumption. There is a need to spread awareness among the communities regarding the quality of the water. 


\section{Introduction}

Potable water is the fundamental need of man to sustain life. Potable water is defined as the water that is free from disease producing microorganisms and chemical substances which are deleterious to health. Water is a good solvent and picks up impurities easily. Pure water is tasteless, colorless, and often called the universal solvents (Choudhury et al., 2016). The provision of potable water to the public by the municipality is necessary to prevent health hazards (Sailaja et al., 2015). Drinking water should not be use only for human consumption but also for washing/ showering and domestic food preparation. Animals use same water for drinking and can also contaminate through direct defecation and urination. (Sarwade and Kamble., 2014). Continual improvement in the quality of water for purposes of drinking, domestic consumption, personal hygiene and certain medical situations is among the top challenges of the world.

World Health Organization informed that contaminated water, inadequate sanitation and poor hygiene cause over $80 \%$ of disease in developing countries (WHO, 1998). Worldwide waterborne diseases are the cause of death and suffering of millions of people, especially, children in developing countries. (Asadullah et al., 2013) Water becomes contaminated by pathogens such as coli form group bacteria, Salmonella and dysentery causing bacilli. Non pathogenic faecal organisms are best indicators of faecal pollution. However in all cases faecal coli form contents and E. coli is used as the major tool in the assessment of the health risk borne pathogen in water. Several water analyses have been regularly conducted by different scientific groups across the country (Vyas et al., 2015). Fecal pollution of drinking water may introduce a variety of intestinal pathogens which may cause disease from mild gastro-enteritis to severe and sometimes fatal dysentery, diarrhea, cholera, typhoid, hepatitis, giardiasis etc. (Crown, 1986; Wanda, 2006). Therefore, potable water is tested for an indicator of human or animal waste known as coli form bacteria. Ideally drinking water should be free from pathogenic microorganism and free from bacteria indicative of fecal pollution (FEPA, 1999). The E.coli and fecal coli forms may come either by fecal materials of human or other warm-blooded (Choudhury et al., 2016).

Physicochemical parameters of water are important to determine the quality of drinking water as according to WHO (1996) the physical parameters that are likely to give rise to complaint from consumers are colour, taste, odour and turbidity while low $\mathrm{pH}$ causes corrosion and high $\mathrm{pH}$ results in taste complaints. Present study was conducted to investigate physio-chemical and microbiological quality of drinking water that is an access to the educational veterinary institutes of Bidar districts which, in turn, reflects the drinking water quality of whole city.

\section{Materials and Methods}

\section{Sample collected}

Tap water samples $(n=82)$ were collected from 05 tallukas of Bidar district. The samples were subjected to physical analysis. All the samples were collected in sterilized bottles and were stored at $4{ }^{\circ} \mathrm{C}$ till further investigation and analysis of water-quality parameters was carried out as per standard methods of WHO (1971) \& BIS (1991).

\section{Physico-chemical Test}

For the analysis of physicochemical parameters, samples were collected in clean plastic containers previously washed and was 
rinsed with water to be collected. Physicochemical parameters were analysed by following standard methods of APHA, 2005.

The parameters included were hardness, $\mathrm{pH}$ : Electronic method, Temperature: Mercury thermometer, Conductivity $(\mu \mathrm{s} / \mathrm{cm})$ : Electrical conductivity using conductivity meter, Turbidity: Turbidometric method, Total Hardness (mg/l): EDTA Titrimetric method, Erichrome Black. total dissolves solids: TDS meter, color and taste: manually.

Chemical parameters included were nitrates, nitrites, chloride, ammonia, fluoride, lead, arsenic, iron, sulphates and copper. Chemical parameters were tested by using prescribed chemicals and following standard protocols.

\section{Microbiological Evaluation}

The bacteriological examination of water sample includes the most probable number of presumptive coli form as suggested by WHO (1971) \& BIS (1991). The bacteriological quality of the water was tested by following standard protocol of most probable number procedure.

\section{Results and Discussion}

\section{Physical parameter}

\section{pH}

$\mathrm{pH}$ is defined as the negative logarithms of hydrogen ion in concentration water. $\mathrm{pH}$ value below 4.0 produces sour taste and a higher value above 8.5 give alkaline taste.

In the present study, the $\mathrm{pH}$ of the 72 sample shown range from 6.5 to 8.5 which is the acceptable limit by $\mathrm{WHO}$ but the remaining 10 sample, from that 9 sample shown $\mathrm{pH}$ range 8.9-9.3 and one sample shown $\mathrm{P}^{\mathrm{H}}$ 6.1.

\section{Turbidity}

Turbidity makes water unfit for domestic purposes, food and beverage industries and many other industrial uses. In the present analysis, the turbidity of the water sample ranged from 0.5 to 2.85 Nephelometric Turbidity Unit (NTU) which is well below the maximum permissible limit i.e. 5 NTU (WHO).

\section{Total Dissolved Solids (TDS)}

High concentrations of total dissolved solids may cause adverse taste effects. TDS values varied between $437.81 \mathrm{mg} / \mathrm{L}$ and 517.53 $\mathrm{mg} / \mathrm{L}$. The all investigated samples showed within the standard limit prescribed by WHO.

\section{Total hardness}

Hardness in water is due to the natural accumulation of salts from contact with soil and geological formations or it may enter from direct pollution by industrial effluents. Hardness of water mainly depends upon the amount of calcium or magnesium salts or both. In the present study, the total hardness of the 65 sample shown range from 65-145 ppm which is the acceptable range (moderately hard water) for drinking water where as 17 sample shown range from 150250 ppm indicating hard water.

\section{Color and taste}

Water is colorless or has a bluish tinge. Normally the water it is tasteless dissolved oxygen and minerals imparts palatability to drinking water.

\section{Chemical parameter}

\section{Ammonia}

Ammonia produced during first stage of oxidation of nitrogenous organic matter. In 
the present study all the sample were shown negativity towards ammonia.

\section{Arsenic}

Arsnic is a cumulative poison and its presence indicate pollution.it is used as weedicide in agriculture and may contaminate the water supplies. In the present study all the sample were shown negativity towards arsenic.

\section{Chloride (Cl-)}

The most important source of chlorides in the waters is the discharge of domestic. In the present analysis, chloride concentration was found in the range of 50-100 ppm. Chloride shown positive in 07 samples concentration was found in the range of 200-300ppm.

\section{Copper}

Copper is rarely found in natural water. traces of cu can be seen if they are stored in copper cistern/vessel and especially when water is acidic.

\section{Fluoride}

Small concentration of fluoride in drinking water has beneficial effect on human health for preventing dental carries. Higher concentration of fluoride than that of $1.5 \mathrm{mg} / \mathrm{l}$ carry an increasing risk of dental fluorosis and much higher concentration lead to skeletal fluorosis (Vyas et al., 2008).the fluride content of water is under acceptable limit.

\section{Iron $(\mathbf{F e})$}

Iron is considered as essential micronutrient. Long term consumption of drinking water with high concentration of iron may leads to liver diseases (Gyamfi et al., 2012). The iron concentration was recorded, which is under the prescribed limit.

\section{Lead}

Lead is commulative poison and acidic water exert a corrosive action especially when $\mathrm{P}^{\mathrm{H}}$ is between 4.5-6.8 which help to dissolve the lead in water all the sample were negative for lead.

\section{Nitrate and Nitrite $\left(\mathrm{NO}_{3}-\right.$ and $\left.\mathrm{NO}_{2}-\right)$}

The nitrate and nitrite content in the groundwater of study area below MPL. In excessive amounts, nitrate may cause methemoglobinemia in infants, a disease characterized by blood changes.

\section{Sulphate (SO4)}

Sulphate in groundwater is obtained principally from gypsum and anhydrite (Sacks, 1996). Discharge of industrial wastes and domestic sewage tends to increase its concentration. The values of sulphate in the water samples under accepatable limit.

\section{Microbiological evaluation}

\section{Fecal coliform}

Bacterial identification was performed by, Multiple-Tube (MPN) Fermentation Technique (3 test tube set); which involves inoculation of inoculum with the ten-fold difference between each set. The test tube of each set containing MacConkeys broth and Durham's tube were inoculated with different dilutions of the water sample and incubated at $37^{\circ} \mathrm{C}$ for 24 to $48 \mathrm{hrs}$. After the incubation period, the tubes were observed for gas production, the number of the positive tubes were recorded and compared with standard MPN table. Positive cultures were inoculated on EMB agar. Coliform bacteria are considered as "indicator organisms", their presence in water may indicate contamination of water by fecal waste that may contain other 
bacteria, viruses, parasites or pathogenic organisms. In bacteriological analysis Most probable number (MPN) count ranged from 03 to 1100 for 13 samples and rest 69 samples shown negative result for coliforms. From 08 MPN positive samples E.coli was isolated by standard microbiological procedure.

The study concludes that all the physicochemical parameters of the water samples collected from tap water, were within the recommended range of WHO and safe for drinking purpose. But the deterioration in the microbiological quality of water at point-ofcollection and use indicate a contamination after collection we can called it as secondary infection. The decline in water quality during collection and storage reflect poor sanitation and existence of unhygienic human practices. The results indicate that the individual householder is responsible for the pollution. Attention should be given to the collection, storage, and management by additional treatment to control the quality of the treated water in a distribution system and stored household water to prevent excessive microbial growth and any associated occurrence of larger life. Habited water is generally used by animals \& birds \& aquatic life. The disturbance in this biological system \& ecological system may affect health of animals \& birds \& aquatic life. After physicochemical analysis we found that the sample of Potable water and habited water are free from pollution \& ecologically balanced. Although, the present investigation is essentially a primary work and needs to be further investigated to arrive at specified conclusion with respect to clinical implications.

\section{Acknowledgement}

The author is thankful to the department of veterinary public health and epidemiology, veterinary college Bidar for providing financial assistance.

\section{References}

APHA, (2005) Standard methods for the examination of water and wastewater, Washington, D.C. 21st end.

Asadullah, K.Nisa And S. I. Kha(2013) Physico-chemical properties of drinking water available in educational institutes of karachi city. Sci., Tech. and Dev., 32 (1): 28-33, 2013

AWWA, (1999) Waterborne pathogens, Manual of water supply practices, First edition. American water works association, Denver, USA. 285 pp.

Babu, Y. S. and M. R. Mohan (2018) A study on physico-chemical parameters of Errarajan lake of Bangalore rural. Int. J. Sci. Res.Volume-7 | Issue-2 February-2018.

Choudhury, S.S., A.Keot, H. Das, M. Das, C. Baishya, A. Sarma and P.Deka; (2016) Preliminary Physicochemical and Microbiological Analysis of Bahini River Water of Guwahati, Assam, India. Int.J.Curr.Microbiol.App.Sci (2016) 5(2): 684-692

Mukhopadhyay, S. and R.Mukherjee (2013) Physico-Chemical and microbiological quality assessment of groundwater in adjoining area of Tamla Nala, Durgapur, District: Burdwan (W.B), India. International Journal Of Environmental Sciences Volume 4, No 3, 2013.

Roopavathi, C., S. S. Mamatha, and N.S. Raju (2016) Assessment of physicochemical and bacteriological drinking water quality of different sources of H.D. Kote town, Mysore district. Int. Journal of Engineering Research and Application. ISSN: 2248-9622, Vol. 6, Issue 7, (Part -4) July 2016, pp.45-51. 
Sacks, L. A., (1996) Geochemical and isotopic composition of ground water with emphasis on sources of sulfate in the upper floridan aquifer in parts of Marion, Sumter, and Citrus countries, Florida. U.S. Geological survey WRIR, 95(4251), p 47.

Sailaja, V., P. Umamaheswari, K.D.Kumar, P.K.Reddy, G.Rajoji (2015) Physicochemical and microbiological analysis of municipality drinking water. International Journal of Current Research Vol. 7, Issue, 08, pp.1936819372, August, 2015.

Sarwade, A. B. and N. A. Kamble (2014) Evaluation of physicochemical parameters of river krishna, Sangli Maharashtra.Oct. Jour. Env. Res. Vol 2(4):329-337.

Shrinivasa, R. B. and P. Venkateswarlu (2000) Indian Journal of Environment Protection., 20(3), pp 161-164.

Shukla, D., K. Bhadresha, Dr. N. K. Jain, Dr. H. A. Modi (2013) "Physicochemical Analysis of Water from Various Sources and Their Comparative Studies". IOSR Journal Of Environmental Science, Toxicology And Food Technology (IOSRJESTFT) e-ISSN: 2319-2402,p- ISSN: 2319-2399. Volume 5, Issue 3 (Jul. Aug. 2013), PP 89-92.

UNESCO, (1992) Groundwater UNESCO

Environmental and development, briefs no. 2, p 14.
UNESCO, (2000) Groundwater pollution, International Hydrological Programme.

Vyas, H. V. and V. A. Sawant (2008), Seasonal variations in drinking water quality of some bore well waters in urban area of Kolhapur city, Nature environment and pollution technology, 7 (2), pp 261-266.

WHO (2004) Water Treatment and Pathogen Control: Process Efficiency in Achieving Safe Drinking Water. Edited by MarkW LeChevallier and Kwok- Keung Au. IWA, London, UK:

WHO, (1996) Guidelines for drinking water quality, 2nd ed., vol. 2. Health criteria and other supporting information. World Health Organization, Geneva, 68-70.

WHO, (1997) Guidelines for DrinkingWater Quality Vol 3: Surveillance and control of community supplies (Second Edition). World Health Organization, Geneva.

WHO, (2004) Safe Piped Water: Managing Microbial Water Quality in Piped DistributionSystems. Edited by Richard Ainsworth. ISBN: 184339 039 6. Published by IWA Publishing, London, UK.

WHO, (2011) Guidelines for Drinking Water Quality, WHO Press, Geneva, Switzerland, 4th edition.

\section{How to cite this article:}

Dhote Lina, Arun Kharate, Basavaraj Awati and Saste Ashwini. 2019. A study on Physicochemical and Microbiological Evaluation of Tap Water of Bidar District, India. Int.J.Curr.Microbiol.App.Sci. 8(04): 290-295. doi: https://doi.org/10.20546/ijcmas.2019.804.033 